\title{
KI NERJA KARYAWAN DITINJAU DARI PROMOSI JABATAN , KOMPETENSI , DAN INSENTIF PADA KARYAWAN PT POS INDONESIA (PERSERO) CABANG SURAKARTA
}

\author{
Rizka Nur Hidayah ${ }^{1}$, Eny Kustiyah, ${ }^{2}$ Sri Hartono $^{3}$ \\ ${ }^{1}$ Mahasiswa Manajemen Fakultas Ekonomi Universitas Islam Batik Surakarta \\ ${ }^{2) 3)}$ Dosen Fakultas Ekonomi Universitas Islam Batik Surakarta \\ Email : Rizkahidayah027@gmail.com
}

\begin{abstract}
The purpose of this study are: 1) To determine the effect of simultaneous promotion of positions, competencies, and incentives on the performance of employees of PT Pos Indonesia (Persero) Surakarta branch. 2) To determine the effect of promotion of positions, competencies, and incentives on the performance of employees of PT Pos Indonesia (Persero) Surakarta branch. Data collection method used was a questionnaire method to 58 employees as respondents. The sampling technique used is the incidental sampling method. Data analysis methods used include: test instruments (validity and reliability), hypothesis testing (multiple linear regression analysis, t-test, $f$ and coefficient of determination $(R 2$. The results of the descriptive analysis showed that respondents were male (55.2\%) and female (44.8\%). All data from the questionnaire have passed the test instrument. For testing the results of the $f$ test that the value of $F$ $(14,158)>F$ table $(2.78)$ with a probability of $0,000(p<0.05)$. This means that the Fcount in the Ho region is rejected, which means that it has a significant effect between the job promotion, competence and incentives simultaneously on the employee performance. From the results of the t-test the results of job promotions have a negative influence on employee performance variables. This is evident from tcount ($0.066)>$ ttable (2.004) with a significance value $>\alpha(0.05)$. The competency variable also has a positive and significant effect on employee performance. This is because tcount $(3,439)>$ ttable $(2,004)$ with a significance value $<\alpha(0.05)$. Incentive variables also have a positive and significant effect on employee performance. This is because tcount (2.687) $>$ ttable (2.004) with a significance value $<\alpha(0.05)$. The results of the analysis in this study obtained an R2 value of 0.409 (40.9\%). This means that the job promotion, competence and incentives is able to contribute $40.9 \%$ to the employee performance. While the remaining $59.1 \%$ is influenced by other variables outside this study such as leadership, motivation, work environment, work stress, etc.
\end{abstract}

Keywords: promotion, competence, incentives, employee performance

\section{PENDAHULUAN}

Keberhasilan dan kelangsungan suatu industri sangat dipengaruhi oleh sumber daya manusia yang dimiliki. Sumber daya manusia merupakan salah satu sumber daya yang harus ada dan yang paling penting dalam sebuah perusahaan, karena manusia merupakan unsur dasar yang dapat melaksanakan pekerjaan dan organisasi . Sumber daya manusia mempunyai peran yang sangat penting dalam perusahaan, karena itu sudah sewajarnya bila pihak perusahaan memberikan perhatian lebih melalui kebijakan - kebijakan yang sudah dipilih. Saat ini banyak masalah yang muncul di perusahaan yang berkaitan dengan sumber ketenagakerjaan terutama kinerja pegawai, oleh karena itu masalah yang berkaitan dengan kinerja harus ditemukan jalan keluarnya. Pegawai memiliki peranan yang sangat penting dan mereka sebagai penggerak utama demi kelancaran kinerja di perusahaan. Selain itu, tidak dapat dipungkiri lagi bahwa manusia merupakan sumber daya yang potensial dan sangat strategis pula perannya dalam berbagai macam bentuk organisasi (Rande, 2016). 
Pengembangan SDM dapat dilakukan dengan berbagai cara, diantaranya melalui promosi jabatan, kompetensi dan pemberian insentif. Dengan adanya target promosi, kompetensi dan pemberian insentif karyawan akan merasa dihargai, diperhatikan, dibutuhkan dan diakui kemampuan kerjanya oleh atasan sehingga mereka akan menghasilkan keluaran (output) yang tinggi. Apabila target promosi, kompentensi dan insentif dilaksanakan dapat mengoptimalkan sumber daya manusia yang dimiliki organisasi . Penilaian kinerja terhadap karyawan merupakan tolak ukur utama dalam pengembangan SDM di lingkup perusahaan (Rahayu, 2017) .

Diberlakukannya promosi jabatan di sebuah perusahaan menjadi dorongan bagi sumber daya manusia untuk menunjukkan kinerja yang baik. Oleh karena itu sebuah hal yang wajar apabila karyawan sangat mengharapkan adanya proses yang baik dari penilaian kinerja sehingga mereka memiliki kesempatan dan dapat memperbaiki jabatan mereka yang saat ini dijabat . Jadi penilaian kinerja saat ini harus sesuai dengan proses dari penilaian kinerja di sebuah perusahaan. Ketiadaan promosi jabatan pada organisasi menyebabkan penurunan kinerja. Akan tetapi dalam kasus umum yang terjadi adalah sebuah proses penilaian kinerja yang cenderung kekurangan bahkan tidak memiliki dampak positif terhadap karir karyawan maka akan berdampak buruk pada karyawan. Karyawan akan menganggap pekerjaan yang mereka lakukan selama ini merasa tidak dihargai (Alimuddin, 2017).

Kompetensi pegawai masih merupakan faktor penting yang mendorong kualitas dan efisiensi pada organisasi sektor publik. Seorang pegawai yang memiliki kompetensi yang tinggi seperti pengetahuan, ketrampilan, kemampuan dan sikap yang sesuai dengan jabatannya masing - masing akan selalu termotivasi untuk memberikan hasil kinerja yang maksimal dalam perusahaan. Hal ini terjadi karena dengan adanya kompetensi yang dimiliki pegawai tersebut dalam melaksanakan tugas yang telah dibebankan oleh perusahaan dapat menjadi kunci keberhasilan suatu perusahaan yang dipengaruhi oleh sumber daya yang ada di perusahaan tersebut SDM maupun finansial. Apabila terjadi masalah di perusahaan antara lain: inisiatif dalam mengerjakan pekerjaan masih rendah dan kerjasama dalam memecahkan permasalahan antar rekan kerja masih rendah maka kualitas dan efisiensi pegawai akan berdampak buruk bagi perusahaan (Alimuddin, 2017) .

Pemberian insentif dilakukan untuk meningkatkan kinerja pegawai terhadap output yang dihasilkan. Insentif merupakan salah satu jenis penghargaan yang berhubungan dengan penilaian kinerja pegawai . Semakin tinggi kinerja pegawai, semakin besar pula insentif yang diberikan oleh perusahaan / instansi. Apabila insentif yang diberikan terhadap pegawainya belum cukup untuk memenuhi kebutuhan, akan mengakibatkan penurunan semangat kerja yang berdampak pada kinerja pegawai di perusahaan. Jika pihak perusahaan membiarkan masalah itu terjadi akan berakibat fatal bagi kelangsungan hidup perusahaan (Djuwarto, Istiatin, \& Hartono, 2017). Selain itu menurut Rukmini (2017), kompensasi juga berpengaruh terhadap kinerja karyawan suatu perusahaan.

PT Pos Indonesia (Persero) cabang Surakarta merupakan perusahaan jasa yang bergerak dalam sektor jasa antar paket dan pembayaran tagihan . PT Pos Indonesia (persero) adalah salah satu cabang perusahaan di surakarta yang beralamatkan di Jl. Jend. Sudirman No. 8 sedangkan pusatnya berada di Jakarta . Perusahaan ini mempunyai karyawan sejumlah 133. Permasalahan yang dihadapi dalam perusahaan antara lain seperti tidak ada dampak positif dengan diadakannya promosi jabatan di perusahaan, inisiatif dalam mengerjakan pekerjaan masih rendah, kerja sama dalam memecahkan suatu permasalahan antar rekan kerja masih rendah, dan bonus yang diberikan belum cukup sehingga semangat kerja karyawan akan 
menurun dan keluaran ( output) yang dihasilkan kurang maksimal . Perusahaan harus melakukan evaluasi setelah melaksanakan kegiatan operasional di perusahaan sehingga hasil kinerja karyawan menjadi lebih baik dari sebelumnya .

Dari latar belakang tersebut, maka peneliti berpendapat layak melakukan penelitian dengan judul “ Kinerja Karyawan ditinjau dari Promosi Jabatan, Kompetensi dan Insentif pada Karyawan PT Pos Indonesia (Persero) cabang Surakarta ”.

\section{TINJAUAN PUSTAKA Kinerja Karyawan}

Kinerja merupakan gambaran mengenai tingkat pencapaian pelaksanaan suatu program atau kebijakan dalam rangka mewujudkan sasaran, tujuan, visi, dan misi di lingkup organisasi / perusahaan yang dituangkan melalui perencanaan strategis suatu organisasi tersebut (Moeheriono, 2012) .

Kinerja adalah hasil suatu pelaksanaan dan pekerjaan , baik bersifat fisik / material maupun non fisik / non material (Widodo, 2015) .

(Sopiah \& Sangadji, 2018) Kinerja dari kata job performance atau actual performance ( prestasi kerja atau prestasi sesungguhnya yang dicapai oleh seseorang ) yaitu hasil kerja yang dicapai oleh seorang pegawai secara kualitas dan kuantitas dalam melaksanakan tugasnya sesuai dengan tanggung jawab yang diberikan kepadanya .

Berdasarkan pengertian - pengertian di atas, dapat dikemukakan bahwa kinerja adalah suatu hasil kerja yang dapat dicapai oleh seorang atau sekelompok orang dalam suatu organisasi baik secara tugas dan tanggung jawab masing - masing serta sesuai dengan standar yang ditentukan oleh perusahaan.

(Sopiah \& Sangadji, 2018) diperlukan juga obyektivitas penilai agar penilaian menjadi adil dan tidak subjektif serta pengukuran kinerja dapat dilakukan melalui indikator - indikator berikut :

1) Ketepatan waktu dalam menyelesaikan tugas

2) Penyelesaian pekerjaan melebihi target

3) Bekerja tanpa kesalahan .

Menurut (Widodo, 2015) kinerja dipengaruhi oleh :

1) Kualitas dan kemampuan pegawai, yaitu hal yang berkaitan dengan pendidikan / pelatihan, etos kerja, motivasi kerja, sikap mental dan kondisi fisik pegawai .

2) Sarana pendukung, yaitu hal yang berkaitan dengan lingkungan kerja ( keselamatan kerja , kesehatan kerja , sarana produksi , teknologi ) dan hal - hal yang berkaitan dengan kesejahteraan pegawai ( upah / gaji , jaminan sosial , keamanan kerja ) .

3) Supra sarana, yaitu hal - hal yang berkaitan dengan kebijaksanaan pemerintah dan hubungan industrial manajemen .

\section{Promosi Jabatan}

Promosi berarti perpindahan dari suatu jabatan ke jabatan lain yang mempunyai status dan tanggung jawab yang lebih tinggi dari sebelumnya (Kadarisman, Manajemen Pengembangan Sumber Daya Manusia Edisi Pertama Cetakan Pertama, 2012) .

Promosi merupakan sesuatu hal yang belum tentu mengakibatkan tambahnya penghasilan, namun pada dasarnya bertambah tanggung jawab nya . Dan akibat tambahnya tanggung jawab tersebut, akan bertambah pula penghasilan, tetapi tidak selalu demikian (Kadarisman, Manajemen Pengembangan Sumber Daya Manusia Edisi Pertama Cetakan Pertama, 2012) . 
Promosi adalah proses perpindahan yang memperbesar authority dan responsibility karyawan ke jabatan yang lebih tinggi dari jabatan yang sebelumnya di dalam suatu organisasi sehingga kewajiban, hak, status dan penghasilan semakin besar (Syahyuni, 2018) .

Berdasarkan beberapa definisi diatas maka promosi jabatan dapat diartikan sebagai perpindahan posisi jabatan yang sangat di inginkan bagi karyawan agar kinerja yang dihasilkan lebih meningkat dari jabatan sebelumnya serta memiliki dampak positif bagi keberlangsungan perusahaan .

(Syahyuni, 2018) merumuskan indikator - indikator dalam proses promosi jabatan sebagai berikut :

1) Kejujuran

2) Disiplin

3) Prestasi Kerja

4) Kerjasama

5) Kecakapan

6) Loyalitas

7) Kepemimpinan

8) Komunikatif

9) Pendidikan

\section{Kompetensi}

(Moeheriono, 2012), Kompetensi adalah suatu karakteristik yang mendasari seseorang berkaitan dengan efektivitas kinerja individu yang memiliki hubung an kausal atau sebab akibat dengan kriteria yang dijadikan sebagai acuan, efektif, pada situasi tertentu di perusahaan .

(Andriyanto \& Subakti, 2018) , Kompetensi adalah suatu kemampuan yang dilandasi oleh keterampilan dan pengetahuan yang didukung oleh sikap kerja serta penerapannya dalam melaksanakan tugas dan pekerjaan di tempat kerja yang berdasarkan pada persyaratan kerja yang ditetapkan oleh perusahaan .

(Moeheriono, 2012) , Kompetensi adalah karakteristik dasar personel yang menjadi faktor penentu seperti sukses tidaknya seseorang dalam mengerjakan suatu pekerjaan atau pada situasi tertentu dalam lingkup organisasi maupun perusahaan .

Berdasarkan beberapa definisi diatas maka kompetensi dapat diartikan sebagai suatu keahlian atau kemampuan yang harus dimiliki setiap pegawai diperusahaan dan sesuai dengan bidang pekerjaan masing - masing sehingga akan menghasilkan kinerja yang lebih baik lagi .

(Andriyanto \& Subakti, 2018), Indikator dari kompetensi sebagai berikut :

1) Motif

2) Sifat

3) Konsep Diri

4) Pengetahuan

5) Keterampilan

(Moeheriono, 2012) Faktor - faktor yang mempengaruhi kompetensi , baik dari dalam ( internal ) maupun dari luar (eksternal), yaitu :

1) Bakat bawaan, bakat yang sudah ada dan melekat sejak mereka dilahirkan

2) Motivasi kerja yang tinggi

3) Sikap, motif dan nilai cara pandang

4) Pengetahuan yang dimiliki baik dari pendidikan formal maupun non formal

5) Keterampilan atau keahlian yang dimiliki

6) Lingkungan hidup dari mereka sehari - hari . 


\section{Insentif}

Insentif adalah bentuk pembayaran yang berkaitan dengan kinerja dan gainsharing , sebagai pembagian keuntungan bagi karyawan di perusahaan akibat peningkatan produktivitas atau efisiensi biaya (Kadarisman, Manajemen Kompensasi Cetakan Pertama, 2012).

(Kadarisman, Manajemen Kompensasi Cetakan Pertama, 2012), Insentif adalah penghargaan / imbalan yang diberikan untuk memotivasi pekerja / anggota organisasi agar lebih semangat dan produktivitas kerjanya tinggi , sifatnya tidak tetap atau sewaktu - waktu .

(Kadarisman, Manajemen Kompensasi Cetakan Pertama, 2012), Insentif adalah elemen penghasilan atas balas jasa yang diberikan manajer secara tidak tetap pada kondisi pencapaian prestasi kerja karyawan di perusahaan / organisasi .

Berdasarkan pengertian-pengertian di atas, dapat dikemukakan bahwa Insentif adalah strategi untuk meningkatkan produktivitas dan efisiensi waktu saat bekerja baik kelompok maupun individu di perusahaan .

(Tandri, Sasongko, \& Puspitaningtyas, 2018), lima indikator yang digunakan untuk mengukur insentif, yaitu :

1) Kinerja

2) Lama kerja

3) Senioritas

4) Kebutuhan

5) Keadilan dan kelayakan

\section{METODOLOGI PENELITIAN}

Penelitian ini menggunakan data primer yang diperoleh dari karyawan PT Pos Indonesia (persero) cabang Surakarta . Metode pengumpulan data yang digunakan adalah metode kuisioner dengan 58 karyawan sebagai responden. Teknik pengambilan sample yang digunakan adalah insidental sampling. Metode analisis data yang digunakan antara lain : uji instrument ( validitas dan reliabilitas ) dan uji hipotesis ( analisis regresi linier berganda, uji t , uji f , dan koefisien determinasi (R2).

\section{Hipotesis}

Hipotesis dalam penelitian ini adalah :

1) Promosi Jabatan, Kompetensi dan Insentif berpengaruh signifikan terhadap kinerja karyawan di PT Pos Indonesia (Persero) cabang surakarta .

2) Promosi Jabatan berpengaruh positif dan signifikan terhadap kinerja karyawan di di PT Pos Indonesia (Persero) cabang Surakarta .

3) Kompetensi berpengaruh positif dan signifikan terhadap kinerja karyawan di di PT Pos Indonesia (Persero) cabang surakarta .

4) Insentif berpengaruh positif dan signifikan terhadap kinerja karyawan di PT Pos Indonesia (Persero) cabang Surakarta .

\section{HASIL PENELITIAN DAN PEMBAHASAN}

Hasil analisis deskriptif menunjukan bahwa responden berjenis kelamin laki - laki $(55,2 \%)$ dan perempuan $(44,8 \%)$. Semua data dari penyebaran kuisioner telah lolos uji instrument . 
Hasil uji asumsi klasik :

1) Uji Normalitas

Berdasarkan hasil perhitungan uji Kolmogorov Smirnov dapat diketahui bahwa p-value adalah 0,095. Nilai p-value ternyata lebih besar dari $\alpha(\mathrm{p}>0,05)$, maka dapat disimpulkan sebaran data nya normal .

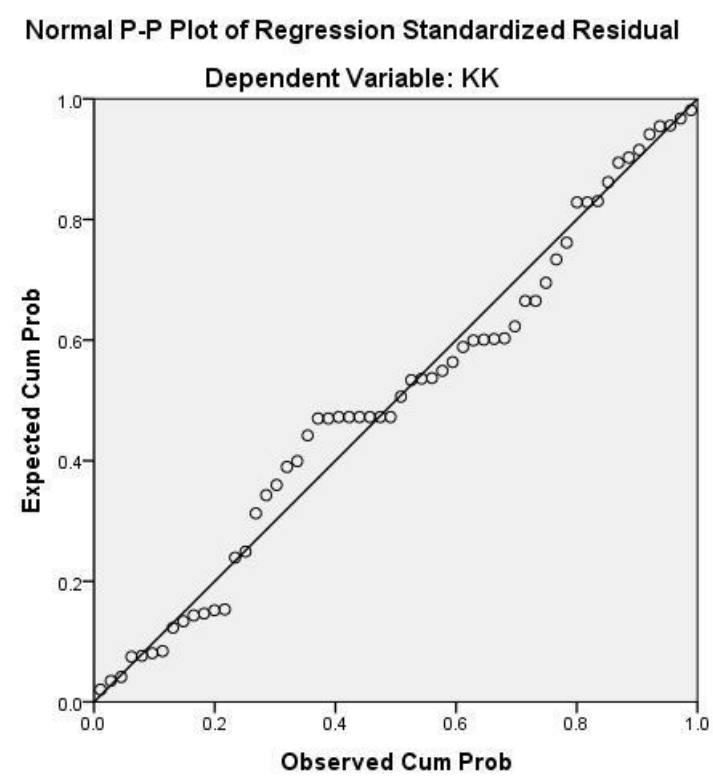

2) Uji Multikolineritas

Tabel 2 Hasil Uji Multikolineritas

\begin{tabular}{|c|c|c|}
\hline Variabel & Toleransi & VIF \\
\hline Promosi Jabatan & 0,3439 & 2,277 \\
\hline Kompetensi & 0,666 & 1,502 \\
\hline Insentif & 0,549 & 1,823 \\
\hline
\end{tabular}

Berdasarkan tabel diatas dapat disimpulkan bahwa model regresi tersebut tidak terjadi multikolineritas karena nilai VIF $<10$ dan Toleransi $>0,1$.

3) Uji Hesteroskedastisitas

Tabel 3 Hasil Uji Hesteroskedastisitas

\begin{tabular}{|c|c|}
\hline Variabel & $t_{\text {hitung }}$ \\
\hline Promosi Jabatan & $-1,124$ \\
\hline Kompetensi & 1,439 \\
\hline Insentif & 0,441 \\
\hline
\end{tabular}


Berdasarkan tabel diatas menunjukan bahwa semua variabel bebas memiliki nilai $\mathrm{p}$ diatas 0,05 sehingga semua variabel bebas tersebut bebas dari masalah hesteroskedastisitas

Untuk pengujian uji $\mathrm{f}$ diperoleh hasil bahwa nilai $\mathrm{F}$ hitung $(14,158)>\mathrm{F}$ tabel $(2,78)$ dengan probabilitas sebesar $0,000(\mathrm{p}<0,05)$. Hal ini menunjukkan F hitung berada pada daerah Ho ditolak artinya terdapat pengaruh yang signifikan dari promosi jabatan , kompetensi, dan insentif secara simultan terhadap kinerja karyawan . Model persamaan regresi disusun sebagai berikut :

$$
\mathrm{Y}=5,051-0,004 \cdot X_{1}+0,256 \cdot X_{2}+0,200 \cdot X_{3}
$$

Dari hasil uji t diperoleh hasil promosi jabatan berpengaruh negatif terhadap kinerja karyawan . Hal ini terbukti dari nilai t hitung $(-0,066)<\mathrm{t}$ tabel $(2,004)$ dengan nilai signifikansi $>\alpha(0,05)$. Kompetensi berpengaruh positif dan signifikan terhadap kinerja karyawan . Hal ini terbukti dari nilai t hitung $(3,439)>t$ tabel $(2,004)$ dengan nilai signifikansi< $\alpha(0,05)$. Demikian juga insentif berpengaruh positif dan signifikan terhadap kinerja karyawan . Hal ini terbukti dari nilai t hitung $(2,687)>t$ tabel $(2,004)$ dengan nilai signifikansi< $\alpha(0,05)$. Hasil analisis dalam penelitian ini menunjukkan $R^{2}$ sebesar 0,409 $(40,9 \%)$. Hal ini berarti promosi jabatan, kompetensi dan insentif mampu berkontribusi sebesar $40,9 \%$ terhadap kinerja karyawan . Sedangkan sisanya sebesar 59,1\% dipengaruhi oleh variabel lain diluar penelitian misalnya kepemimpinan, motivasi, lingkungan kerja , stress kerja dll.

\section{KESIMPULAN}

Dari pembahasan dan hasil diatas, dapat ditarik beberapa kesimpulan :

a. Promosi Jabatan, Kompetensi dan Insentif secara simultan berpengaruh positif dan signifikan terhadap Kinerja Karyawan PT Kantor Pos (persero) cabang Surakarta . Semakin baik karyawan mendapatkan promosi jabatan yang lebih tinggi dan sesuai dengan SOP perusahaan, lebih berkompeten serta profesional dalam bekerja dan pemberian insentif berdasarkan kebutuhan, hasil kerja karyawan dapat meningkatkan kinerja .

b. Promosi Jabatan berpengaruh negatif terhadap Kinerja Karyawan PT Kantor Pos (persero) cabang Surakarta .

c. Kompetensi berpengaruh positif dan signifikan terhadap Kinerja Karyawan PT Kantor Pos (persero) cabang Surakarta . Semakin berkompeten dalam bekerja dapat meningkatkan kinerja karyawan .

d. Insentif berpengaruh positif dan signifikan terhadap Kinerja Karyawan PT Kantor Pos (persero) cabang Surakarta . Semakin baik pemberian insentif nya dapat meningkatkan kinerja karyawan .

\section{Saran}

Berdasarkan hasil penelitian , pembahasan, dan kesimpulan yang diperoleh, maka saran yang dapat diberikan adalah sebagai berikut :

a. Kompetensi karyawan harus lebih baik lagi, pihak perusahaan perlu mengadakan pelatihan dan pendidikan setelah diterima kerja dengan tujuan menghasilkan kinerja karyawan yang optimal .

b. Pihak manajemen perlu memperhatikan dalam hal pemberian insentif seperti tepat waktu, adil dan sesuai hasil kerja karyawan . 


\section{DAFTAR PUSTAKA}

Alimuddin, A. (2017). Peran Sistem Manajemen Kinerja , Kompetensi Pegawai dan Promosi Jabatan dalam Meningkatkan Kinerja Karyawan. Jurnal Ekonomi Modernisasi, 13(3), $155-165$.

Andriyanto, H., \& Subakti, A. G. (2018). Pengaruh Pelatihan , Motivasi , dan Kompetensi terhadap Kinerja Karyawan ( Studi Kasus Hotel Sahid Jaya Lippo Cikarang ). Journal of Indonesian Tourism, Hospitality, and Recreation, I(2), 55 - 69.

Djuwarto, Istiatin, \& Hartono, S. (2017). Pengaruh Insentif , Kompetensi , dan Lingkungan Kerja terhadap Kinerja Pegawai Dinas Pekerjaan Umum Kabupaten Sukoharjo. Jurnal Akuntansi dan Pajak, 18(1), 83-93.

Kadarisman, M. (2012). Manajemen Kompensasi Cetakan Pertama. Jakarta: RajaGrafindo Persada.

Kadarisman, M. (2012). Manajemen Pengembangan Sumber Daya Manusia Edisi Pertama Cetakan Pertama. Jakarta: RajaGrafindo Persada.

Moeheriono. (2012). Pengukuran Kinerja Berbasis Kompetensi , Edisi Revisi Cetakan Pertama. Depok: RajaGrafindo Persada.

Rahayu, S. (2017). Pengaruh Promosi terhadap Kinerja Karyawan pada PT Garuda Metalindo. Jurnal Kreatif, V(1), 59-75.

Rande, D. (2016). Pengaruh Kompetensi terhadap Kinerja Pegawai pada Dinas Perhubungan , Komunikasi , dan Informatika Kabupaten Mamuju Utara. e Journal Katalogis, IV(2), 101-109.

Rukmini, R. (2017). Pengaruh Kompensasi Dan Lingkungan Kerja Terhadap Kinerja Karyawan Pada CV. Roda Jati Karanganyar Tahun 2016. Jurnal Akuntansi dan Pajak, 17(02).

Sopiah, \& Sangadji, E. M. (2018). Manajemen Sumber Daya Manusia Strategik Edisi Pertama . Yogyakarta: Andi Offset.

Syahyuni, D. (2018). Hubungan Antara Kinerja Karyawan dengan Promosi Jabatan pada Unit Taman Marga Satwa Ragunan Dinas Kehutanan Provinsi DKI Jakarta. Widya Cipta, II(1), 76-82.

Tandri, R. D., Sasongko, \& Puspitaningtyas, Z. (2018). Pengaruh Motivasi Kerja dan Insentif terhadap Kinerja Aparatur Pemerintah Kecamatan Ambulu Kabupaten Jember. Majalah Ilmiah "Dian Ilmu", XVIII(1), 71-89.

Widodo, S. E. (2015). Manajemen Pengembangan Sumber Daya Manusia Cetakan Ke Satu. Yogyakarta: Pustaka Pelajar. 